\section{2：1 型粘土鉱物表面における} 吸着水分子の束縛力評価への

\section{分子軌道法の適用}

\author{
長崎晋也・梅村康洋 \\ 田中 知・鈴木篤之
}

東京大学大学院工学系研究科システム量子工学専攻

更113 東京都文京区本郷 7-3-1

（1997 年 4 月 10 日受付；1997 年 7 月 9 日揭載決定）

\section{Application of Molecular Orbital Calculation for Evaluating Binding Force of Water Molecules Sorbed on Surface of $2: 1$ Type Clay Mineral}

Shinya NAGASAKI, Yasuhiro UMEMURA, Satoru TANAKA and Atsuyuki SUZUKI

Department of Quantum Engineering and Systems Science The University of Tokyo 7-3-1 Hongo, Bunkyo-ku, Tokyo 113

(Received April 10, 1997; Accepted July 9, 1997)

We evaluate the bonding force subjecting on the water molecule sorbed on the surface of $2: 1$ type clay mineral by using semi-empirical molecular orbital calculation, and compare it with the binding forces of soild and liquid phases of water. We can consider that molecular orbital calculation is a useful and helpful tool for characterizing the properties of water molecules present in the clay minerals.

\section{1. 序}

\section{論}

我が国における高レベル放射性廃棄物地層処分システ ムの概念では, $2: 1$ 型粘土鉱物（モンモリロナイト） を主成分とするベントナイトが人工バリアの候補材とし て有力である。最近の地層処分安全評価研究において, 圧密されたベントナイト中における放射性核種の移行が 拡散で支配されるとともに，そこでの核種の吸着が安全 評価上重要な役割を果たすことが明らかにされた

圧密ベントナイトに周辺の地層中から地下水が浸入す
ることでベントナイトは膨潤する。圧密膨潤ベントナイ ト中における核種の拡散や吸着の多くは高々 $10 \AA$ の幅 しかない層間における現象であり, 水分子の大きさを考 慮した場合, 層間の幅方向には水分子は 3 分子しか存在 することはできない。したがって, 圧密ベントナイト中 における核種の拡散や吸着現象を理解するためには, ベ ントナイト層間における水の特性を理解する必要があ る。従来, 粘土鉱物中にもともと含まれる水に関しては 粉末を用いた研究が精力的に行われてきた ${ }^{2 \sim 6)}$ 。しかし, 圧密され膨潤された粘土鉱物内の水に関しては, 層間の みならず粒界の水の状態すら不明であり, Pusch ら”の 概念が提唱され, Torikai ら ${ }^{8)}$ のトリチウム水の活性化エ ネルギーが報告されているに過ぎない。これは, 圧密さ れかつ膨潤された状態を維持したまま実験的に水の状態 を測定することが困難であることに起因している。

そこで本研究では, 前報9)で粘土鉱物表面における電 荷分布の評価に有効であることを報告した半経験的分子 軌道を用いて，2:1 型粘土鉱物表面の水に作用する束 縛力を評価し, Torikai らの結果と比較することで, 分 子軌道法が粘土鉱物内の水分子の特性を明らかにする手 法として有効となる可能性があるか否かの検討を行っ た。

\section{2. 計 算 方 法}

本研究では, 前報と同じ体系の $2: 1$ 型粘土鉱物クラ スターを用い, 同形置換をしていないクラスターを clay 0 , 四面体での置換を行ったクラスターを clay 4 , 八面体での置換を行ったクラスターを clay 8 と呼ぶ。ま た, 半経験的分子軌道計算プログラムとして, MOPAC Ver. 6 （J.P. Stewart）を用いた。

本研究では, 最初に粘土鉱物の共存しない状態での水 分子間の結合力を評価するため, 水分子を水の結晶構造 で配置させた系（固相）と, 水分子を乱雑に配置させた 系（液相）における水分子間の結合力を, 系を構成する 水分子の数をパラメータとして計算した。水は六方晶系 に属する結晶で, 1 個の水分子は隣接する 4 個の水分子 と水素結合を形成し, 中心の水分子は正四面体的構造を している ${ }^{10)}$ 。本研究での水の結晶構造は正四面体構造を 取るように水分子を配置させた。液体の水に関しては, 1 気圧 $0^{\circ} \mathrm{C}$ での体積が氷に比べ $8.3 \%$ 程度減少する一 方, 温度の上昇に伴い分子間距離が増加する。厳密には 系の温度などを決めて体積変化を考慮すべきではある が, 本研究では簡単のため体積は変化しないとし, 同一 体積内で水分子を乱雑に配置させることで液相系とし 


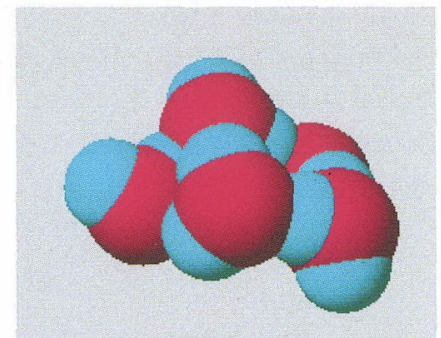

Solid Phase

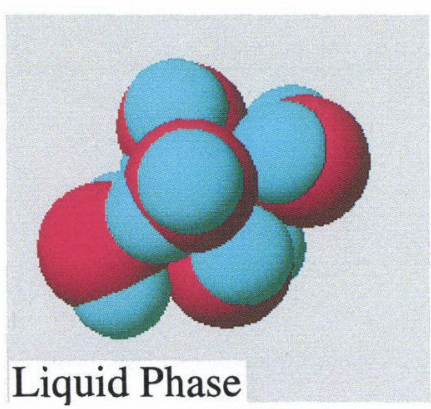

Liquid Phase

Fig. 1 Model structure of water molecules in solid and liquid phases.

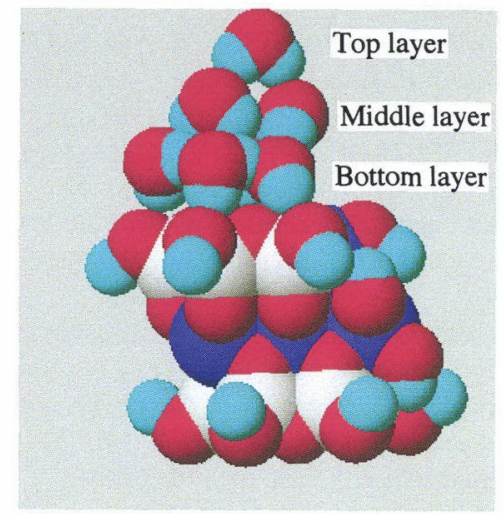

Fig. 2 Model structure of three-layer water molecules sorbed on $2: 1$ type clay mineral.

た。Fig. 1 に固相と液相での水分子の配置例を示す。次 に，2:1 型粘土鉱物クラスタ一上に水分子を 3 層並べ, 各層を構成する水分子が受ける束縛力を割価し, 上で求 めた固相中, 液相中での結合力と比較した。クラスター 上に水分子を 3 層配置したときの例を Fig. 2 に示す。最 後に, クラスターを並列に 2 個重小合わせて, そのクラ スタ一間に水分子を 3 層配置して各水分子が受ける束縛 力を評価した。

\section{3. 計算結果と考察}

\section{1 バルクの固相中，液相中の結合力}

Fig. 3 に, 固相中での水分子間の結合力と液相中での 水分子間の結合力を, 系を構成する水分子数をパラメー タとして7 分子まで設定して評価した結果を図示する。 図中で実線は固相の結果を, 波線は液相の結果を示して いる。 2 本の直線の勾配から, 固相における水分子間の 結合力は $5.5 \mathrm{kcal} / \mathrm{mol}$, 液相における結合力は $4.4 \mathrm{kcal} /$ $\mathrm{mol}$ と評価された。確認のため, 系を構成する水分子数 を 10 個ならびに 20 個として評価したが結果は同じであ ったため,これらの值を採用することとした。また，こ

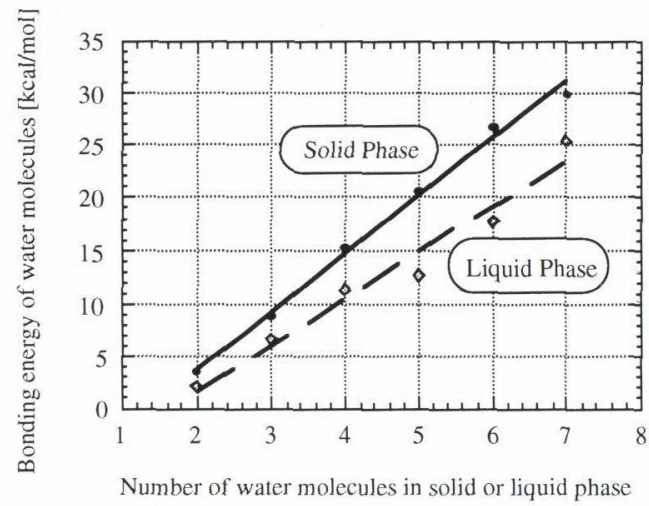

Fig. 3 Dependence of bonding energy of water molecule in solid and liquid phases on number of water molecules composing each phase.

れらの值は異なる理論計算に基づく報告値と一致してい る $^{11 \sim 13)}$ 。

\section{2 粘土鉱物表面における水分子の束縛力}

粘土鉱物の表面に吸着した 3 層の水分子に作用する束 縛力の評価結果について, クラスター 1 個での結果を Table 1 に, また層間を模擬したクラスター 2 個での結 果を Table 2 に示す。両方の系とも，粘土鉱物表面に直 接吸着している水分子について束縛力という観点からは 水（固相）と同程度の束縛を受けている一方, 直接吸着 していない水分子（Table 1 では第 2 層, 第 3 層, Table 2 では第 2 層) はバルクの水（自由水と言えるかもしれ ない）と同程度の束縛力を受けていることがわかる。粘 土鉱物内での同形置換を受けた場合 $(-1$ の負電荷を带 びる）には，受けていない clay 0 と比較してわずかに束 縛力が大きくなっており，また clay 4 の方が clay 8 より も束縛力が大きい。四面体での置換の方がより表面に近 い格子上での置換であり, 表面での吸着や束縛力に何ら かの影響をより強く及ぼしているものと考えられる。分 子軌道法を用いた本研究の結果から, 圧密され膨潤した 
Table 1 Binding energy of water molecules in three layers sorbed on surface of clay minerals.

\begin{tabular}{l|c|c|c}
\hline & clay 0 & clay 4 & clay 8 \\
\hline Top layer & -5.33 & -5.58 & -5.49 \\
\hline Middle layer & -4.68 & -4.89 & -4.68 \\
\hline Bottom layer & -4.03 & -4.33 & -4.28 \\
\hline \multicolumn{4}{|c}{$[\mathrm{kcal} / \mathrm{mol}]$}
\end{tabular}

Table 2 Binding energy of water molecules sorbed in interlayer of clay mineral.

\begin{tabular}{l|c|c|c}
\hline & clay 0 & clay 4 & clay 8 \\
\hline Top layer & -5.23 & -5.31 & -5.28 \\
\hline Middle layer & -4.42 & -4.55 & -4.47 \\
\hline Bottom layer & -5.23 & -5.31 & -5.28 \\
\hline \multicolumn{4}{|c}{$[\mathrm{kcal} / \mathrm{mol}]$}
\end{tabular}

ベントナイト中に存在し得る 3 層の水分子のうち, 直接 粘土表面に吸着している層中の水分子は水（固相）と同 程度の束縛力を, またそれらの層に挟まれた中間層の水 分子はバルクの水（液相）と同程度の束縛力を受けてい ると予測される。これは, トリチウム水の拡散の活性化 エネルギー値という観点から検討した Torikai ら ${ }^{8)}$ の実験 結果と一致する。つまり, 分子軌道法により評価された 束縛力という観点からの水の状態と, 拡散実験により評
価された活性化エネルギーという観点からの水の状態は 一致する。このことは, 分子軌道法が，圧密粘土鉱物表 面あるいは層間における水分子の特性を理論的側面から 評価するための有効な手法となる可能性があることを示 唆している。

\section{文献}

1) 安 俊弘, 池田孝夫, 大江俊昭, 菅野 毅, 坂本義 昭, 千葉 保, 塚本政樹, 中山真一, 長崎晋也, 板 野且典, 藤田智成 : 日本原子力学会誌 37, 59 (1995).

2) S.L. Swartzen-Allen and E. Matijević: Chem. Rev. 74, 385 (1974).

3) G. Sposito and R. Prost: Chem. Rev. 82, 553 (1982).

4) J. Conard, H. Estrade-Szwarckopf, A.J. Dianoux and C. Poinsignon: J. Physique 45, 1361 (1984).

5) 佐藤 努 : 日本原子力学会誌 36, 405 (1994).

6) 佐藤 努 : 鉱物学雑誌 25, 99 (1996).

7) R. Pusch and H. Hoekmark: Eng. Geol. 28, 379 (1990).

8) Y. Torikai, S. Sato and H. Ohashi: Nucl. Technol. 115, 73 (1996).

9）長崎晋也, 梅村康洋, 田中 知, 鈴木篤之: 表面科 学 18, 702 (1997).

10) 大瀧仁志 : “イオンの水和” (共立出版, 1990) p. 16.

11) S.H. Suck: Tetrahedron 44, 7373 (1988).

12) S.H. Suck: Theor. Chem. Acta 70, 3 (1986).

13) M.S. Choe: Tetrahedron 44, 7379 (1988). 